\title{
VACUUM OF FACT OR VACUOUS THEORY: A REPLY TO PROFESSOR KRIPKE
}

\author{
Thomas H. JaCKSON ${ }^{\dagger}$ and Alan Schwartz ${ }^{\dagger \dagger}$
}

In 1979, Thomas Jackson and Anthony Kronman asked the related questions why debtors offered security in personal property and whether a security interest would increase the welfare of a debtor and all of its creditors, taken as a group. ${ }^{1}$ These questions inspired a vigorous debate. ${ }^{2}$ The participants have taken as their starting point the Modigliani \& Miller irrelevance proposition that if capital markets are perfect, information is perfect, all actors have homogeneous expectations, bankruptcy costs are zero, and no taxes exist, a firm cannot increase its value by altering its capital structure. ${ }^{3} \mathrm{~A}$ change in the mix of a firm's debt, from unsecured debt to secured, is an alteration in its capital structure. Since such a change cannot increase the firm's value and since it is costly for firms to offer security, the irrelevance proposition predicts that no secured debt will be issued. Because secured debt is common, participants in the "security interest debate" therefore proceed in two ways: they relax the strong assumptions that Modigliani \& Miller made to see whether the new models thereby obtained predict security, or they add additional factors-moral hazard, risk aversion, and the like-to see whether models so derived can explain the ob-

$†$ Professor of Law, Stanford University.

tt Maurice Jones, Jr. Professor of Law, University of Southern California Law Center; Professor of Law and Social Science, California Institute of Technology.

The authors thank Douglas Baird, Ronald Gilson, Anthony Kronman, Stephen Morse, Matthew Spitzer, and Jeff Strnad for helpful comments on earlier drafts.

1 Jackson \& Kronman, Secured Financing and Priorities Among Creditors, 88 YALE L.J. 1143 (1979).

2 See D. Baird \& T. Jackson, Security Interests in Personal Property 354-67 (1984); Levmore, Monitors and Freeriders in Commercial and Corporate Settings, 92 Yale L.J. 49 (1982); Schwartz, Security Interests and Bankruptcy Priorities: A Review of Current Theories, $10 \mathrm{~J}$. Legal STud. 1 (1981) [hereinafter cited as Schwartz, A Review]; Schwartz, The Continuing Puzzle of Secured Debt, 37 Vand. L. REv. 1051 (1984) [hereinafter cited as Schwartz, The Continuing Puzzle]; White, Efficiency Justifications for Personal Property Security, 37 VAND. L. Rev. 473 (1984).

3 See Modigliani \& Miller, The Cost of Capital, Corporation Finance and the Theory of Investment, 48 AM. Econ. Rev. 261 (1958); see also Miller, Debt and Taxes, 32 J. Fin. 261 (1977); Modigliani \& Miller, Corporate Income Taxes and the Cost of Capital: A Correction, 53 AM. Econ. REv. 433 (1963). The proposition is proved rigorously in Stiglitz, On the Irrelevance of Corporate Financial Policy, 64 Am. Econ. Rev. 851 (1974). An informal description of the proposition and its relevance to security interests is found in Schwartz, The Continuing Puzzle, supra note 2, at $1052-55,1066-68$. 
served data. All but one of the debaters claim to have found at least a tentative explanation for the existence of secured debt. Although the details of these explanations differ, they have a common theme: security-the debaters claim, exists and is justified because it is efficient; that is, a debtor can compensate those of its creditors whose position is worsened by security while remaining better off than had it not granted a security interest. Alan Schwartz, on the other hand, argues that no good explanations for the presence of security exist. Thus, he believes, claims of its efficiency are premature.

This debate is important for two reasons. First, personal property security is common. Second, if security has good effects-it reduces costs-the law should bless it; if security has bad effects-it exploits the uninformed-the law should restrict it. Hence, it is important for lawyers to understand the consequences traceable to the use of security in commercial transactions.

Professor Homer Kripke is a new entrant to the security interest debate. ${ }^{4}$ His conclusion that security exists because it increases welfare is similar to the conclusions of other scholars, but his methodological stance differs sharply from prevalent current practice. Kripke rejects the Modigliani \& Miller irrelevance proposition and the entire methodological tradition from which it derives. Rather, Kripke claims, the security interest issue should be studied with "the techniques that Robert Braucher and [he] applied as drafters of the present form of UCC article 9" and with "the kind of reasoning that [they] submitted to the Review Committee composed of practicing lawyers, judges, and academics of an older generation."' Kripke's article deserves notice because it attempts to change the terms in which the security interest debate should be conducted. His substantive explanations for the existence of security are also worth study because it is through them that his methodological claims are cashed out.

Part I of this reply shows that Kripke's methodology, taken on its own terms, is deficient. Part II shows that his explanations for the existence of security are incomplete or false. The lesson is that wisdom in result is unlikely to derive from error in method.

\section{The Kripke Methodology}

Two quotes, both criticisms of Schwartz, illustrate Kripke's meth-

Kripke, Law and Economics: Measuring the Economic Efficiency of Commercial Law in a Vacuum of Fact, 133 U. PA. L. Rev. 929 (1985).

s Id. at 932. 
odological claims:

$[\mathrm{M}] \mathrm{y}$ strongest disagreement with Schwartz's approach is that he seems to consider law-and-economics research as consisting of rummaging through economic hypotheses formulated in other contexts for other purposes, in the hope of finding a fit for his current problem, instead of formulating his own hypotheses by first looking at the facts and at history. ${ }^{6}$

... Schwartz [should have] ventured into the factual world by even casual inquiry to formulate a hypothesis instead of trying to adapt a theory formulated in different factual contexts .... .

Actual forays into the market are necessary because scholars cannot obtain "an understanding of the business world" by "reliance on secondary sources." Instead, Kripke believes, "research can best be carried out by factual inquiry among those practicing in the field" - that is, by surveys of lawyers and business people. ${ }^{10}$

The methodological position these statements imply thus holds that (i) the scholar, in solving a problem, should look at the real world directly, obtaining facts about it from its inhabitants; (ii) it is unnecessary-indeed, harmful - to use hypotheses or theories "formulated in different factual contexts" to understand the problem at hand; (iii) rather, the scholar should formulate both positive and normative hypotheses by observing the facts themselves. This position may have initial appeal to persons innocent of social science methodology but is actually without merit. The first claim is both trivially correct-look at the facts--and false-use only the reports of involved actors. Such reports are helpful, but they have two significant limitations: people may not fully understand the causes of their own conduct, and people may attempt to make self-description consistent with self-image, to the disservice of truth. Hence, serious scholars do not advocate using only these reports when other data are available. ${ }^{11}$

- Id. at 964 .

7 Id. at 969. At another point Kripke states, "I simply cannot believe that the study of abstract concepts developed in other contexts for other purposes can in any way contribute to an understanding of practical commercial law or policy." Id. at 969.

8 Id. at 932.

Id. at 983 .

10 See id. at 980. If surveys are inconvenient, commercial law scholars, Kripke advises, should learn about the world from participating in the American Bar Association and reading such journals as The Business Lawyer, The Commercial Law Journal, and the NCFA Journal. See id. at 984 . These journals often contain articles by lawyers and business people.

${ }^{11}$ The classic book that makes this point is E. WebB, D. Campbell, R. 
Regarding Kripke's second claim, we acknowledge that actual phenomena sometimes are so novel that analysts may have to formulate novel hypotheses to explain them. But it is only common sense to ask whether previous theories can illuminate the issue at hand. Secured lending transactions take place in markets. Jackson \& Kronman and Schwartz "rummage through economic hypotheses formulated in other contexts" because these hypotheses attempt to explain how markets perform. Kripke's methodological claim that this search is fruitless would be persuasive only if he could show that the laws of market behavior have no application to secured lending. Kripke does not even attempt such a showing. Theories developed in particular contexts may of course lack generality, but to acknowledge this is not to consign old theories to the flames. ${ }^{12}$

Kripke's last claim, that scholars should formulate hypotheses by observing the facts, is also flawed. To believe that moral norms can be deduced from factual observation is to commit the naturalistic fallacy, that "ought" is deducible from "is." 13 The long-standing existence of secured credit does not mean that it is advantageous to society, any more than the long-standing existence of cartels means that they are socially desirable. Further, Kripke misconceives the process of hypothesis development. Scholars first formulate a tentative hypothesis to explain a phenomenon. In formulating the hypothesis, they use the facts they know, though these may be known only from casual observation or second hand. Then they test the tentative hypothesis against observation, refining or abandoning it as the facts dictate. Coming to the "real world" without a hypothesis yields only confusion because then a scholar has no way to choose, from among the countless facts that exist, those facts that could help to explain the phenomenon under study. A

SChwartz \& L. Sechrest, Unobtrusive Measures: NonREactive Research in THE SOCIAL SCIENCES 1-34 (1966).

12 Perhaps a better way to put our point is to examine the implications of Kripke's rejection of "hypotheses formulated in other contexts." Theories are invented to solve particular problems in particular contexts. According to Kripke, scholars should invent new theories whenever they work in different contexts. In economics, for example, Cournot discovered the law of demand by speculating about the actions of mineral spring proprietors. See R. Ekelund \& R. HÉBert, A History of EcoNOMic TheORY AND MeThod 254-56 (2d ed. 1983). According to Kripke, economists should ignore Cournot and reinvent the law of demand problem by problem. It is odd, moreover, to view the irrelevance proposition as a "hypothesis formulated in other contexts." It was formulated to explain differentiated capital strictures. Such structures often include secured debt.

18 See G. Moore, Principia Ethica 9-15 (1959). Long ago, Richard Danzig conclusively criticized this error in reasoning as it appeared in commercial law. See Danzig, A Comment on the Jurisprudence of the Uniform Commercial Code, 27 STaN. L. Rev. 621, 627-31 (1975). 
hypothesis provides a basis for focusing on what in the real world is relevant. For example, the Modigliani \& Miller irrelevance proposition is valuable not because its assumptions reflect the real world-they do not-but because the proposition orders the scholar's inquiry: which assumption, when relaxed, could explain how firms can increase their value by issuing different kinds of ownership forms-a differentiated ownership structure-instead of issuing claims that all have the same level of priority? ${ }^{14}$ The actual process of hypothesis formulation sometimes is misunderstood because the world seems meaningful yet people seldom explicitly formulate hypotheses to explain it. The cognitive psychologists teach, however, that everyone uses heuristics to classify phenomena, although only some are aware of doing so. ${ }^{16}$ Scholars must be among this latter group. Kripke's prescription for ignorance, staring at the facts until a hypothesis emerges, therefore is both unwise and impossible to implement.

Kripke's methodological position is so false that he himself cannot consistently follow it. His footnotes frequently make reference to secondary sources, ${ }^{16}$ and he uses models and relies on concepts invented in different factual contexts. ${ }^{17}$ But his belief in his own position and his

14 Assumptions play a heuristic role in the Modigliani \& Miller analysis. A heuristic assumption is made though it is known to be false because the assumption permits progress to be made on a problem. The scholar making the assumption intends to relax it after the progress has been made. Economists and natural scientists use heuristic assumptions. See Musgrave, "Unreal Assumptions" in Economic Theory: The F-Twist Untwisted, 34 KYKLOS: INT'L REv. FOR SOC. SCI. 377, 382-86 (1981).

is See, e.g., Judgment Under UnCERTAinty: Heuristics and Biases (D. Kahneman, P. Slovic \& A. Tversky eds. 1982); R. NisbetT \& L. Ross, Human INFERENCE: STRATEgIeS AND SHORTCOMINGS OF SOCIAL JUdGMENT (1980).

${ }_{16}$ See, e.g., Kripke, supra note 4, at 932 n.15, 942 n.42, 942 nn.52 \& 55, 952 n.85.

${ }_{17}$ See, e.g., Kripke, supra note 4, at 952, 965-66. Kripke's attempt to describe the Modigliani \& Miller irrelevance proposition as a "weak" analytic tool is itself weak. $\mathrm{He}$ first rejects the proposition because it fails to predict security. Yet prediction is not the only function of theory. See Gilson, Value Creation By Business Lawyers: Legal Skills and Asset Pricing, 94 Yale L.J. 239, 252 \& n.32 (1984). The irrelevance proposition is and from the beginning was meant to be useful as a heuristic device. See Musgrave, supra note 14, at 382-85; Schwartz, The Continuing Puzzle, supra note 2, at 1052-55, 1066-68. Kripke also claims that the irrelevance proposition is weak because it is not universally accepted. On this ground, however, his attack attempts to derive support principally from people working within the framework of the irrelevance proposition, and who do so by relaxing assumptions-the same method used by other participants in the security interest debate. See Kripke, supra note 4, at _ \& n.128. These sources, whether persuasive or not in the explanations they offer, attempt precisely the interaction of theory and the real world that we advocate. The only real challenges to Modigliani \& Miller that Kripke notes are a paper by Durand in 1959, Durand, The Cost of Capital, Corporation Finance, and the Theory of Investment: Comment, 49 AM. Econ. REv. 639 (1959) [hereinafter cited as Durand, The Cost of Capital], and a book by Graham, Dodd, and Cottle from 1962, A. GraHaM, D. DoDD \& S. Cottle, Security ANalysis 320-22 (4th ed. 1962). Durand, however, is widely 
attempts to follow it are severely handicapping. Kripke is trying to play tennis with a baseball bat and the results are predictable-a lot of swings but no points scored.

\section{Kripke's Substantive Case}

Kripke offers three substantive explanations for the existence of personal property security. ${ }^{18}$ First, security reduces the risks of creditors who take it. These creditors thus can economize on credit investigations, and consequently loan transactions proceed more quickly. ${ }^{19}$ Second, secured lending increases the value of a debtor's assets. Therefore, security does not worsen the position of unsecured creditors. Indeed, matters may improve for the unsecured creditors because the new assets may help debtors to prosper. Since security makes some better off and none worse off, it is efficient. ${ }^{20}$ Third, some loans will not be made

regarded as the first person to advance what later became the irrelevance proposition, in Durand, Cost of Debt and Equity Funds for Business: Trends and Problems of Measurement, in National Bureau of Economic Research, Conference on Research in Business Finance 215 (1952) [hereinafter cited as Durand, Cost of Debt]. See R. Brealey \& S. Myers, Principles of Corporate Finance 373 (2d ed. 1984) (noting that Durand deserves credit for setting out the issues that Modigliani \& Miller later solved). In that article, Durand states that the contention "that conservative increases in bonded debt do not increase the risk borne by the common stockholders" has "little merit; it runs counter to the rigorous analysis offered by the advocates of [what became the irrelevance proposition]." Durand, Cost of Debt, supra, at 230. This is hardly stunning support for Kripke's suggestion that the Modigliani \& Miller irrelevance proposition is controversial.

18 The difficulties with Kripke's argument are revealed early in his article when he claims that he is asking the question that occupies participants in the security interest debate: "[W]hy should the law allow discrimination in favor of certain creditors, through the device of contractual security, while invalidating discrimination in favor of other creditors through contractual arrangement with the debtor for preferred payment?" Kripke, supra note 4, at 965 (footnote omitted). This question is both easy and the wrong question. Professors Baird and Jackson have pointed out that when dealing with other property claimants the question Kripke puts concerns only ostensible ownership. See Baird \& Jackson, Possession and Ownership: An Examination of the Scope of Article 9, 35 Stan. L. REv. 175, 179-90 (1983); see also Baird, Notice Filing and the Problem of Ostensible Ownership, 12 J. Legal STUd. 53 (1983). The key distinction between allowing secured credit and not allowing other contractual forms of priority in payment is that secured credit exists within a legal system designed to provide notice to third parties of the existence of this priority, so other purchasers of the collateral can account for the fact that "what they see" may not be "what they get." Other private agreements do not provide the requisite notice, and therefore generate a negative externality. Legal bans exist, in part, to prevent such uncorrected externalities. Kripke's question also is the wrong one: the question that occupies participants in the security interest debate is whether, assuming an adequate solution to the ostensible ownership problem, the state's permission of secured credit advances the net aggregate welfare of the debtor and its creditors.

19 See Kripke, supra note 4, at 946-49. Kripke states, "The importance of this point cannot be overemphasized." Id. at 948 .

20 See id. at 937-41. 
without security, and therefore some new assets will not be acquired; hence, security is essential to the economy. ${ }^{21}$ Taken singly or together, Kripke argues, these claims show both why security exists and that it is good. His claims, however, are incomplete or false.

\section{A. Security Reduces the Secured Creditor's Risks}

No participant in the security interest debate denies that security reduces the risks that secured creditors face. But focusing on the obvious reduction in the risk to one creditor is not responsive to the correct question: whether security reduces the secured creditor's risk more than it increases the risk of unsecured creditors. Unless it does, the existence of secured credit is at best a wash and, because of the unavoidable costs it introduces (such as filing and search costs), inefficient in the aggregate. Kripke, because he rejects the irrelevance proposition, ignores a subset of the relevant players - the unsecured creditors-and thus gives what is at best an incomplete explanation-that secured debt exists because of its risk reduction properties for secured creditors.

\section{B. Secured Lending Increases the Debtor's Assets}

In modeling the security interest problem, Jackson \& Kronman, implicitly, and Schwartz, explicitly, use examples that suppose a debtor's assets to remain constant in value from the time of credit extension to the time of default. ${ }^{22}$ According to Kripke, only persons ignorant of the "highly practical" commercial law field could use such examples, because informed persons know that secured loans add to a debtor's assets and increase its earnings prospects. The unrealistic nature of the examples used by Jackson \& Kronman and Schwartz, Kripke believes, causes them to commit the fundamental error of viewing "secured credit as a zero-sum game" in which a secured creditor's gain is just the unsecured creditor's loss. ${ }^{23}$ Rather, because secured credit adds to a debtor's wealth it is a positive-sum game, creating gains in excess of losses for all of the players taken as a group. ${ }^{24}$ Kripke's knowledge of the real world, he argues, thus enables him to show the efficiency of the secured lending form. In contrast, the methodology used by Jackson \& Kronman and Schwartz causes them to remain ig-

21 See id. at 960-61.

22 See Jackson \& Kronman, supra note 1, at 1147-48; Schwartz, A Review, supra note 2 , at 8-9.

${ }^{23}$ Kripke, supra note 4, at 936.

24 See Kripke, supra note 4, at 936-41. 
norant of this world and so to commit fatal error. ${ }^{25}$

Kripke's claim is confused because it conflates the question whether money should be borrowed with the question under what terms it should be borrowed. ${ }^{26}$ No one denies that a debtor can use borrowed funds to increase its net wealth. ${ }^{27}$ The issue is whether secured borrowing can increase a debtor's net wealth over what it would have been with an unsecured loan. To answer this question, the analyst must focus on the effect of altering the terms under which money is borrowed.

A firm contemplating acquisition of a new asset faces both an investment decision and a financing decision, but Kripke fails to keep these two decisions separate. Thus he repeatedly compares a debtor that has a new asset and a new senior secured creditor to a debtor that has neither. This is erroneous because the issue in contention does not concern the investment decision, whether to buy the asset, but rather the financing decision, how to pay for it. To resolve the question how asset purchases should be financed, Kripke should have compared a debtor that has a new asset and a new secured creditor to a debtor that has the same new asset and a new unsecured creditor. Given that this is the relevant comparison, however, the asset need not be new. It is necessary to do no more than Jackson \& Kronman and Schwartz did, which was to compare the effect on a debtor's net wealth of alterations in the loan contracts it may make, independently of whether the loans themselves are used to increase the assets a debtor owns. As we shall next see, it is Kripke's blurring of the distinction between whether a firm should borrow at all and under what terms it should borrow that causes him to make the fundamental mistake.

25 Kripke's focus on increases in the debtor's assets leads him to concede that some secured debt is inefficient. This is because he apparently believes that when the question is one of taking security interests in existing assets, the advantages to one creditor come at the expense of the other. See id. at 937 . Although Kripke is speaking only of taking security on account of an antecedent debt, his point implicitly calls into question the wisdom of allowing anyone to take a security interest in existing assets. In this respect, at least, Kripke may be calling into question more of the structure of article 9 than Jackson \& Kronman did. For if explanations such as differential monitoring skills carry any force, they would apply equally to security interests in existing assets. Kripke dismisses the problem of taking security interests in existing assets as unimportant, without recognizing the damage he has done to much of his argument. See id. at 93738.

28 We discuss here the borrowing of money while Kripke focuses on the acquisition of assets. These are different ways of describing the same phenomenon because credit enables a debtor to purchase things. We later discuss asset financing explicitly.

${ }^{27}$ Kripke suggests that Modigliani \& Miller "come close" to denying this. Id. at 937 n. 35 . The irrelevance proposition, however, suggests only that the form of borrowing (debt or equity) does not matter. Our point stands: borrowing can sometimes increase net worth. 
To perceive the effect of Kripke's error, first realize that before loans are made debtors possess wealth. When a particular debtor borrows a sum without security it has a new asset-the borrowed funds or what they purchased-and a new liability. The debtor also has an altered prospect of future success. The debtor's creditors, including the creditor who made the loan at issue, have claims on the debtor's new and old wealth and on its prospects. In the event of default the creditors' claims will be satisfied on a pro rata basis. Next suppose that the same sum is borrowed with security. Neither the debtor's net wealth nor its prospects are changed from what they would have been had the loan been unsecured, for the debtor is helped by the money, not the mortgage. What has changed is the configuration of claims to the debtor's wealth and prospects: the secured lender now has a prior claim to the extent of its loan. As Part IIA above and much previous work has shown ${ }^{28}$ given the assumptions that Modigliani \& Miller make the consequent lower interest rate the secured creditor charges will be offset exactly by the higher interest rates of the debtor's other creditors, who will adjust to the presence of security. Hence, security seemingly produces no net gains for debtors. ${ }^{29}$ The scholarly task, then, is to show that the apparent offset is not real-that a mere alteration in the configuration of claims to the debtor's wealth and prospects actually can generate net credit cost reductions. That borrowing money to use in a firm's business can increase the debtor's wealth is both true and irrelevant to this task. Kripke, however, uses only the wealth-increasing properties of borrowing to explain the existence of security. It is this conflation of the question whether to borrow with the question whether to mortgage that is the real error, for it causes Kripke to believe that he has solved the problem of why security exists when he has in fact made no progress. The following discussion of Kripke's major example further illustrates this basic point.

Kripke sets up a balance sheet ${ }^{30}$ of a debtor that looks like this at

28 See supra note 2.

29 A proof of the proposition that security cannot increase net wealth even when the prospect-increasing property of new credit is explicitly considered is on file with the University of Pennsylvania Law Review.

so See Kripke, supra note 4, at 938-39. 
time 1:

\section{Balance Sheet 1}

Assets
Liabilities and Net Worth

$\$ 20,000 \quad$ Unsecured Creditor $A \quad \$ 40,000$ $\underline{60,000}$ $\$ 100,000$

The debtor then buys an inventory of automobiles and starts to market them, borrowing the money on a secured basis, yielding at time 2 the following balance sheet:

\section{Balance Sheet 2}

\section{Assets}

Liabilities and Net Worth

Cash

Inventory

Auto Repair

Equipment
$\$ 20,000$

60,000

$\underline{80,000}$
Unsecured Creditor $A$

Secured Creditor $B$

60,000

TOTAL

$\$ 160,000$

Owners' Equity

60,000

$\$ 40,000$

TOTAL

$\$ 160,000$

Kripke draws the following conclusion from this:

[W] hen security is taken for new consideration, the pool of assets available for the unsecured creditors is not necessarily diminished. The old unsecured creditors have not given up any claim to assets on which the new secured creditor has a security interest, because the old creditors had no claim to the assets until the debtor negotiated to obtain them by meeting the supplier's terms. The new creditor furnished additional assets in return for the security. ${ }^{31}$

Kripke admits that the increased leverage increases the risk of Creditor $A$ "somewhat," because "if the new assets prove insufficient to satisfy the debt to $B$, then $B$ will attempt to recoup this deficiency by competing with $A$ for the remaining pool of assets." 32 But he apparently believes that he has shown that this increase in risk does not offset the benefits of permitting Creditor $B$ to have priority with respect to the 
new asset. $^{33}$

He has, however, shown nothing of the sort. ${ }^{34}$ First, assuming the asset would be acquired without security, and absent explanatory factors (such as differential monitoring skills or specialization), the existence of security alters only priorities, nothing more. If Creditor $B$ wins with respect to the asset, Creditor $A$ clearly does not. Thus, a world that allows Creditor $B$ to take a security interest necessarily increases the risk to Creditor $A$, an increase that interest rates will reflect. Also, if the debtor plans to borrow again, future creditors will be disadvantaged by the security and so will charge higher interest rates to offset any possible earlier gains.

\section{Without Security Some Assets Will Not Be Acquired}

Kripke claims that without security assets often would not be acquired. Since new assets increase wealth and since loans with security make their acquisition possible, security is efficient. This claim cannot show that security is desirable. There is a distinction between acquiring the asset and the way in which it is acquired. The legal world places a number of constraints on the agreements that creditors and debtors can reach. For example, a deal to give a particular creditor priority without public filing is prohibited because it is disadvantangeous to other creditors, even though the creditor seeking the secret priority would not sell the asset without it. Similarly, to say that creditors will not finance asset purchases without security cannot be grounds for permitting security unless it is also shown that security is desirable (or at least not bad). The question posed by the Modigliani \& Miller irrelevance proposition is whether security, with notice, is in that same category of things that should be prohibited even though particular creditors might desire them, because they are detrimental to all creditors taken as a group. Kripke ignores this point. Thus, his claim that security is good

ss See id. at 940. If Kripke had made such a showing, he would have disproved Durand, on whom he relies. See Durand, Cost of Debt, supra note 17, at 228-31.

${ }^{34}$ Moreover, as Jackson \& Kronman observed in their 1979 article, Kripke's "new asset" world is not nearly as clear-cut as this. Any new loan (viewed from the moment after the loan is made) increases a debtor's assets (as well as its liabilities) by the amount of the loan. But not all new loans should be purchase money. The question is why limit purchase money priority to identifiable assets. Jackson \& Kronman suggested the answer had to do with the nature of debtor misbehavior and the possibility that the proceeds of general loans might be frittered away, ultimately leaving a new liability but no corresponding asset. See Jackson \& Kronman, supra note 1, at 1164-78 (expanding on that rationale). In exploring that question, these authors felt compelled to attempt an answer to an even more basic one: why a "first in time" rule? In answering that, they were led back to the question: why security at all? See id. at 1178-82. 
because without it some loans would not be made is unpersuasive. ${ }^{35}$

Further, as shown above, under certain assumptions secured loans are more costly to debtors than unsecured loans. Then there seemingly exists a loan contract without security that would make both the debtor and the (otherwise) secured creditor better off; these parties could split the cost savings that forgoing security makes possible. Hence, the analyst's task is to show why such contracts are sometimes not used. But to show this is to show why security is used. Therefore, Kripke's claim that security is efficient because it makes possible some credit extensions merely restates the major positivist question: why do the parties agree to security? It does not answer this question.

Kripke attempts to respond to this last difficulty by claiming that sales financing without security would have to be done with higher interest rates but that higher interest rates and increased collateral requirements are not perfect substitutes. Put more simply, he asserts that creditors, whether sellers or third-party financers, will not eschew security in favor of higher rates. Consequently, the loan contract without security described in the previous paragraph will never be seen in the real world; debtors will acquire assets in secured lending transactions or will not acquire assets at all. This response is unsound because it implies that the granting of a security interest is a necessary condition to the acquisition of an asset. Kripke acknowledges that much unsecured trade credit and other credit exists, however, and this credit is often used to purchase assets. ${ }^{36}$ Since, as Kripke asserts, unsecured loans are more risky than secured loans, the creditors in these unsecured financing transactions must regard higher interest rates as substitutes for security. ${ }^{37}$ Kripke's claim can be rescued by being restated: in some cases, higher interest rates and security are not substitutes. But

35 Kripke's claim that if the creditor wants something as a condition of a sale, the state should permit it, provides no basis to separate out the demand for security from the demand for purchase money priority. Curing ostensible ownership does provide such a basis, but when that response is offered we no longer are in a world of giving the creditor what it wants, but rather a world of imperfect information with attempts to correct the imperfection. Kripke gives no reason why his claim cannot, and should not, apply as well to an instance in which a creditor will not extend credit unless it is given priority without public filing. Yet Kripke has indicated that he would not advocate abolition of the public filing requirement even if credit would not otherwise be extended. See Kripke, Book Review, 37 Bus. Law. 723, 728 (1982) (reviewing B. Fritch \& A. Reisman, Equipment Leasing-Leveraged Leasing (2d ed. 1980)).

s6 See Kripke, supra note 4, at 972-73, 981-82.

s7 See id. at 972-73. Another way to put the point in the text is to observe that sellers will always sell for cash. Since the financing could come from someone other than the seller, to say that without security an asset will not be acquired is thus to say that no one will finance asset sales on an unsecured basis. As the text shows, however, much unsecured financing exists. 
then Kripke must identify these cases. He makes only one effort, in a footnote, to explain why creditors will not raise interest rates: "many secured lenders may prefer not to be known as interest gougers." 38 This effort is unavailing for two reasons. First, it adds very little to our understanding of when creditors will reject more money in favor of more security just to say that "many" creditors will reject more money. Second, if secured credit cannot increase a firm's value and is costly to obtain, debtors may prefer higher interest rates to security. A desire to retain good will thus may cause lenders to eliminate security rather than require it.

To be sure, lenders sometimes will not raise interest rates in response to increases in debtor demand, even when usury statutes would permit the higher rates. Efforts to explain this behavior, however, do not lend support to Kripke's position. There now are two partially conflicting explanations of voluntary limits on rate increases. Both posit an information asymmetry between debtors and creditors. Credit investigations, it is assumed, do not fully inform creditors of each debtor's character and prospects. Hence, creditors face uncertainty. One story then seeks to explain the existence of credit rationing - the existence of an excess demand for loans in equilibrium. ${ }^{39}$ According to this story, lenders forgo rate increases because of adverse selection and moral hazard. Adverse selection exists because debtors who are willing to pay higher interest rates may, on average, be worse risks; they are willing to pay high rates because they perceive their probability of repaying loans to be low. Therefore, to raise rates in response to increases in demand could cause borrowers to select adversely against lenders: good borrowers go elsewhere and bad borrowers take the higher rates. Similarly, moral hazard-bad behavior after a loan is made-exists because raising the interest rate decreases the return on successful projects. This is said to induce debtors to pursue projects with lower probabilities of success but with higher payoffs when success occurs. As a result of adverse selection and moral hazard, creditors will not raise interest rates monotonically in response to demand; rather, there exists an equilibrium interest rate that maximizes creditor profits while leaving some loan demand unsatisfied. Credit is rationed.

This theory also claims that creditors will not increase collateral requirements in response to debtor demand. ${ }^{40}$ Adverse selection is

38 Id. at 955 n.95.

30 See Stiglitz \& Weiss, Credit Rationing in Markets with Imperfect Information, 71 AM. ECON. Rev. 393 (1981).

${ }^{40}$ See id. at 402-06; see also Ordover \& Weiss, Information and the Law: Evaluating Legal Restrictions on Competitive Contracts, AM. Econ. Rev., May 1981, at 
claimed to explain this phenomenon. Wealthier persons are less risk averse than poorer persons, and wealthier persons can put up the most collateral. Also, debtors may be able to meet collateral requirements because they earned higher returns on prior risky investments, so that those debtors with substantial collateral are just those debtors with high preferences for risk. Hence, increasing collateral requirements may, under plausible conditions, increase the number of risk takers in a pool of potential borrowers sufficiently to lower a creditor's return from what it would have been with lower collateral requirements. If, therefore, credit rationing explains the failure of creditors to raise interest rates in response to demand, then one is left without an explanation for security; when creditors will not raise interest rates, they also will not demand security.

The second explanation for why creditors sometimes will not just increase interest rates also cannot provide an efficiency justification for security. This explanation posits the same information asymmetry just described, and also assumes that the costs to debtors of granting security interests vary inversely with the quality of their loan projects. Then debtors with good projects will offer more collateral as security than debtors with bad projects. Debtors, that is, use security as a device to signal to creditors their creditworthiness, and creditors rely on these signals because they are otherwise imperfectly informed about the debtors. ${ }^{41}$ This theory thus claims that more security is offered by low-risk than by high-risk debtors, while the previous theory claims the reverse. With matters in this state, empirical verification or more theory is badly needed, but having either is unlikely to sustain Kripke's view. As we have seen, if the rationing theory is true, security is unexplained. And if the signaling theory is true, claims for the efficiency of security are premature. As has often been shown, signaling equilibria are not necessarily efficient, nor have any efficiency properties been associated with a security interest signaling equilibrium. ${ }^{42}$

To summarize, Kripke's claim that security is desirable because without it much asset financing would not occur is defective on both normative and positive grounds. That some creditors insist on security cannot of itself demonstrate the normative value of secured lending. Although increased interest rates seem at first blush good substitutes for collateral requirements, explanations for why they sometimes are not

399, 401 (1981) (papers and proceedings).

11 This explanation was first suggested in Schwartz, A Review, supra note 2, at 14-21. A similar version is in Chan \& Kanatas, Asymmetric Valuations and the Role of Collateral in Loan Agreements, 17 J. Money, Credit \& Banking 84 (1985).

12 See Schwartz, A Review, supra note 2, at 14-21. 
good substitutes in actual markets have yet to demonstrate the efficiency of secured credit.

\section{Conclusion}

The novelty of Professor Kripke's entrance into the security interest debate lies in his claim that security interest problems should be analyzed with the tools and evidence available to practicing lawyers. It is doubtful whether practicing lawyers are as badly handicapped in performing intellectual tasks as he asserts, but it is easy to see that Kripke's methodology is utterly bereft of serious intellectual support. No one could get a challenging problem of social policy right using Kripke's approach. Unsurprisingly, his claims to explain security are hackneyed-lenders will not lend without security because security reduces their risks-or confused-security rather than credit itself increases the assets of the debtor. Regardless of the description under which these claims fall, they do not advance understanding of the security interest problem at all. Kripke's unfortunate failure to take the theoretical literature seriously has prevented him from using his vast experience to shed real light on the issues he addresses. Operating in a vacuum of theory is a weak way to demonstrate that others have operated in a vacuum of fact. 